\title{
Öğretmen Olarak Anne Baba Envanteri: Geçerlik ve Güvenirlik Çalışması*
}

\author{
Parent As A Teacher Inventory: The Study of Validity and \\ Reliability*
}

\author{
Emine YILMAZ BOLAT**, Figen GÜRSOY***, Robert STROM****
}

\begin{abstract}
Öz: Ebeveynlerin çocuk yetiştirme tutumlarını değerlendirmek oldukça önemlidir. Bu araştırmanın amacı, "Öğretmen Olarak Anne Baba Envanteri”ni Türkçeye uyarlamaktır. Bu envanter, 3-9 yaş arası çocuğa sahip ebeveynlerin tutumlarını değerlendirmek için kullanılmaktadır. "Öğretmen Olarak Anne Baba Envanteri"ndeki maddeler, ebeveynlerin çocukları ile ilgili duygu ve düşüncelerini belirten durumları belirleyip cevaplamalarını gerektirir. "Öğretmen Olarak Anne Baba Envanteri” ebeveynçocuk arasındaki etkileşimleri yaratıcılık, disiplin, oyun, hayal kırıklığı ve öğretme-öğrenme olmak üzere beş boyut açısından değerlendirmek için oluşturulmuştur. Bu araştırmada, "Öğretmen Olarak Anne Baba Envanteri” Adana'daki 5-6 yaş çocuğa sahip gönüllü 191 anne 160 baba olmak üzere toplam 361 kişiye uygulanmıştır. Bu anne-babalar, Milli Eğitim Bakanlığına bağlı 8 farklı okul öncesi eğitim kurumuna devam eden çocukların ebeveynleri arasından seçilmiştir. Envanterin uyarlanmasında geçerlik güvenirlik çalışmaları için iç tutarlık, cronbach alpha, güvenirlik tekrar test, geçerlik ölçümü faktör yapısı kullanılmıştır. Faktör analizi sonuçları, uyarlanan ölçeğin orijinal ölçeğe benzer şekilde faktör yapısına sahip olduğunu göstermiştir. Ölçeğin Cronbach alpha katsayısı 0.83 olarak elde edilmiştir. Güvenirlik için test-tekrar test korelasyon katsayısı 0.88 olarak bulunmuştur. Orijinal yapısı için bazı uyum testlerine de bakılmıştır. Strom (1984) tarafından geliştirilip Yılmaz Bolat tarafından Türkçeye uyarlanan "Öğretmen Olarak Anne Baba Envanteri”, geçerli ve güvenilir bulunmuştur. Sonuçta $R M S E A=.05, R M R=.03, S R M R I=.06, G F I=.86, A G F I=.84, \mathrm{X}^{2} / \mathrm{sd}: 2.01, \mathrm{X}^{2}: 909.05, \mathrm{p}<0.01$ olarak bulunmuştur.
\end{abstract}

Anahtar Kelimeler: Öğretmen olarak anne baba envanteri, geçerlik, güvenirlik, faktör analizi

\begin{abstract}
Measuring attitudes of parents on rearing is very important. The aim of this research is to adapt the Parent As A Teacher Inventory (PAAT) to Turkish. This instrument is used to measure attitudes of parents who have 3- to 9 year-old children. PAAT instructions inform respondents that they read statements on feelings and think about their child. PAAT is designed to examine interaction between parent and child on five aspects which are creativity, control, play, frustration, and teaching-learning. In this study, PAAT was administered to 351 parents (191 mothers and 160 fathers) living in Adana, Turkey. All subjects were volunteer parents and had children between five and six years of age. The Turkish parents were selected from the children's parents who go to eight kindergartens affiliated to the Ministry of National Education in Adana. Factorial structure, criterion-related validity, test retest reliability and cronbach alpha internal consistency of the version of the inventory were assessed by various statistical analyses. The results of the factor analysis of the scale which was held to reveal the factor structure of the scale seem similar to the original scale. Cronbach alpha correlation coefficient of the scale was found as $\alpha=0,83$. Test-retest reliability coefficient was found as 0,88. PAAT which was developed by Strom (1984) and adapted to Turkish by Yilmaz Bolat was employed in order to measure the criterion referenced validity of the scale. The findings indicated that it was of validity and reliability. Finally, it was founded that fit index values of the model: RMSEA=.05, RMR=.03, SRMRI=.06, GFI=.86, AGFI=.84, $\mathrm{X}^{2} / \mathrm{sd}: 2.01, \mathrm{X}^{2}: 909.05, \mathrm{p}: .00$.
\end{abstract}

Keywords: The parent as a teacher inventory, validity, reliability, factor analysis

\footnotetext{
* III. Uluslararası Okul Öncesi Eğitim Kongresinde (12-15 Eylül 2012, Adana) sözel bildiri olarak sunulmuştur.

** Yard.Doç.Dr., Mersin Üniversitesi, Eğitim Fakültesi, Mersin-Türkiye, e-posta:emineyilmaz@mersin.edu.tr *** Prof.Dr., Ankara Üniversitesi, Sağlık Bilimleri Fakültesi, Ankara-Türkiye, e-posta: gursoy.f@gmail.com **** Prof.Dr., Arizona State University,Tempe-ABD, e-posta: Bob.Strom@asu.edu
} 


\section{Giriş}

Aile, çocuğun gelecek hayata hazırlandığı, iyi kötü, doğru yanlış gibi ahlaki kavramların ve toplum kurallarının öğretildiği, doğuştan getirilen yeteneklerin kullanılma düzeyi üzerinde etkili olan toplumun küçük bir kesitidir. Aile çocukların bilgi ve becerileri edinme ve ilk günden itibaren çocuğun yaşamını şekillendirme gücüne sahip olma açısından en önemli ve etkili bir kurumdur (Özbey, 2010). Ailenin çocuk eğitimine bakış açısı ve çocuk eğitimi konusundaki tutumları, çocuğun gelecek yaşamını da önemli ölçüde etkilemektedir (Kaya, 2002). Özellikle ailenin en önemli bileşenleri olan anne babaların çocuk yetiştirmeye yönelik tutum ve davranışları, çocuğun tüm alanlarda gelişimini etkileyen ve onun gelecekteki davranışlarını şekillendiren önemli bir etken olup, çocuğun toplumun beklentilerine ve değer yargilarına uygun, çevresiyle uyumlu bir birey olarak yetişmesinde büyük öneme sahiptir (Demirkaynak, Aktaş ve Hasipek, 2006). Anne-babaların çocuklarını yetiştirme tarzları, çocukların zekasını, fiziksel yapısını, sosyal ve duygusal gelişimini etkilemektedir (Elibol, 2007).

Anne-baba-çocuk arasındaki etkileşimleri kapsayan çocuk yetiştirme yöntemleri, ebeveynin tutum ve davranışlarını şekillendirmeyi sağlarken, çocuğun gelecekteki davranışlarını da etkiler (Elibol 2007). Çocuk yetiştirmede, çocuğu reddetme yerine, kabullenen, samimi ve istekli bir bakım şeklinde koruma, idare etme, yönetme içerisinde bir disiplin sağlamak yeterlidir (Percira, Canavarro, Cardese, ve Mendonça, 2008). Anne babalar etkili çocuk yetiştirme tutumları ile çocukları istendik davranışlara ve duygusal özelliklere sahip bireyler olarak yetiştirebilirler. Aile, çocuğun gelişimine yardımcı olmak ve çocuğun gelişimini desteklemek için ekonomik ve etkili bir sistem olup çocukların yaşamını şekillendirmede oldukça önemlidir.

Çoğu araştırmacı tarafından farklı sosyal gruplarda yetişen çocuklar ve anaokulundan liseye kadar değişen yaşlardaki çocuklarla ilgili eğitimsel çıktılar üzerinde çeşitli ebeveyn çalışmalarının etkisi denenmektedir. Pekçok anne baba da kendi aile büyüklerinden gördüğü çocuk yetiştirme tutum ve davranışlarını benimsemektedir. Oysa toplumlardaki sosyokültürel ve ekonomik gelişmelerle birlikte çocuk yetiştirme biçimleri de değişmektedir (Tezel Şahin ve Özyürek, 2010). Günümüzde bazı anne babalar ise çocuklara karşı nasıl bir tutum sergilemeleri gerektiği konusunda yeterli bilgi ve beceriye sahip olmadığı için, bu görevlerini yeterince yerine getirememektedir (Warner ve Sower, 2005). Bu nedenle anne babaların çocuk yetiştirme tutumlarını değerlendirme araçlarını geliştirmenin önemli olduğu düşünülmektedir.

$\mathrm{Bu}$ çalışmanın anne babaların çocuk yetiştirme tutumlarının değerlendirilmesine katkı sağlaması, ebeveynlerin çocuklarıyla olan ilişkilerine, sergiledikleri tutum ve davranışlarındaki etkisine dikkat çekmesi ve anne baba eğitimi ile anne babaların çocuk yetiştirme tutumları alanında yapılacak olan çalışmalara katkı sunması açısından önemli olduğu düşünülmektedir. Ayrıca anne babaların çocuk yetiştirme tutumlarını değerlendirme envanteri oluşturması ve uygulamalarda kullanılması açısından da önemli olduğu düşünülmektedir. $\mathrm{Bu}$ araştırmanın amac1, "Öğretmen Olarak Anne Baba Envanteri”ni Türkçeye uyarlamaktır.

\section{Yöntem}

$\mathrm{Bu}$ çalışma, amaçları bakımından tarama modeline uygun şekilde düzenlenmiştir. Bir konuya ya da olaya ilişkin katılımcıların görüşlerinin ya da ilgi, beceri, yetenek, tutum vb. özelliklerinin belirlendiği, genellikle diğer araştırmalara göre daha büyük örneklemler üzerinde yapılan araştırmalara tarama araştırmaları denilmektedir (Büyüköztürk, Çakmak, Akgün, Karadeniz ve Demirel, 2008). Bu araştırma uygulamalı bir araştırmadır. Karasar (2000), uygulamalı araştırmaları, "üretilen bilgilerin değerlendirilmesi ile problemlerin fiilen çözümünü gerçekleştirmeyi, bilimin olayları denetim altına alma işlevini gerçekleştirmeyi, amaçlayan araştırmalardır" şeklinde tanımlamaktadır.

\section{Örneklem/Çalışma Grubu}

Araştırmanın evrenini, Adana il merkezinde bulunan özel ve resmi okul öncesi eğitim kurumlarına devam eden ve normal gelişim gösteren beş-altı yaş grubu çocukların annebabaları oluşturmaktadır. Araştırmanın örneklemini ise, Adana il merkezinde bulunan resmi ve 
özel olan sekiz farklı okul öncesi eğitim kurumuna devam eden 5-6 yaş grubu çocukların anne babaları oluşturmaktadır (191 anne 160 baba). Örneklem seçimi, tesadüfi örnekleme yöntemiyle belirlenmiştir.

\section{Veri Toplama}

Araştırmada, anne-babalar ve çocuklar hakkında kişisel bilgileri elde etmek amacıyla araştırmacı tarafından uzman görüşü doğrultusunda geliştirilen "Genel Bilgi Formu" ile anne babaların çocuk yetiştirme tutumlarını değerlendirmek amacıyla 1984'te Strom tarafından geliştirilmiş ve 1995 yılında yeniden gözden geçirilmiş olan "Öğretmen Olarak Anne Baba Envanteri” (PAAT-Parent As A Teacher Inventory) kullanılmıştır.

"Öğretmen Olarak Anne Baba Envanteri" (Parent As A Teacher Inventory-PAAT), ebeveynlerin çocuklarıyla etkileşimleri konusunda onların düşünce ve hislerini değerlendirmek, çeşitli çocuk davranışlarını değerlendirme standartları ve çocuk davranışlarıyla ilişkili önemli tercihlerini belirlemek amacıyla geliştirilmiş olan bir ölçme aracıdır. Ebeveynlerin çocuklarıyla nasıl etkileşimde bulunduklarını, çocuklarından ne istediklerini ve ne beklediklerini, onların cevapları doğrultusunda çocuklarının davranışları hakkındaki eylemleri ve çocuğun gelişiminin nasıl desteklendiğini ortaya koymaktadır. PAAT, ebeveyn-çocuk arasındaki etkileşimi yaratıcılık, hayal kırıklığı, disiplin, oyun, öğretmeöğrenme olmak üzere beş yönden değerlendirmektedir (Strom 1984a, Strom 1995, Thornburg, Ispa, Gray ve Ponder, 1983). PAAT, anaokulu ve ilköğretim birinci sınıf çocuklarının anne ve babalarının tutumlarını karşılaştırmada, düzenlenen anne-baba eğitim programlarını ve aile katılım çalışmalarını değerlendirmek amacıyla klinik çalışmalarda ve ön test-son testli araştırmalarda değerlendirme aracı olarak kullanılabilmektedir (Beckert, Strom, Strom, Yang, Huang ve Lin, 2004, Grotevant ve Carlson 1989, Strom 1995). Envanterde anne babalar her bir madde için daima, sıklıkla, nadiren ve asla gibi dört farklı seçenekten bir tanesini seçmektedir. Her bir boyutun ve envanterin tamamının puanlaması, anne babanın verdiği cevaba göre 1, 2, 3 veya 4 puan verilerek yapılmaktadır. En olumlu cevaba 4 puan, en olumsuz cevaba ise 1 puan verilmektedir (Grotevant ve Carlson, 1989;, Strom ve Hill, 1979; Strom, 1984a; Strom, Wurster, Betz, Daniels, Graf ve Jansen, 1984; Strom, 1995; Hellen, 1999; Beckert vd., 2004). Envanterde 25 maddede (1, 6, 7, 9, 10, 13, 19, 20, 22, 23, 25, 26, 27, 28 , $32,33,34,36,37,39,41,42,43,45,48$ ) daima cevabına 1, siklıkla cevabına 2, nadiren cevabına 3, asla cevabına 4 puan; diğer 25 maddede ise $(2,3,4,5,8,11,12,14,15,16,17,18$, $21,24,29,30,31,35,38,40,44,46,47,49,50)$ daima cevabina 4 , siklıkla cevabina 3 , nadiren cevabına 2, asla cevabına 1 puan verilerek değerlendirilmektedir (Strom ve Hill 1979; Strom 1984a). PAAT geçerlik güvenirliği için, Strom ve arkadaşları tarafından iç tutarlılık için Kuder Richardson Formula 20 (K-20) ve Cronbach alfa katsayılarına bakılmıştır. Sonuçta, alfa katsayısı .75, iç güvenirliği .83, anne babaların ifadeleri ve davranışları arasındaki tutarlılık \%70-80 olarak saptanmıştır (Grotevant ve Carlson, 1989; Hellen, 1999; Hull ve Nie, 1979; Strom, 1982; Strom vd., 1984; Thornburg vd., 1983).

Verilerin Toplanması ve Analizi

Araştırmaya katılan anne babalarla görüşmeler yapılarak araştırmanın amacı ve ölçme aracı hakkında bilgi verilmiştir. Toplanan veriler faktör analizi tekniği aracıllı̆̆ıla değerlendirilmiştir. Ayrıca madde-toplam puan güvenirliği, Cronbach alfa $(\alpha)$ güvenirliği ve test-tekrar test güvenirliği hesaplanmıştır. Araştırmada veriler bilgisayar ortamında aktarılarak, açımlayıcı faktör analizi için SPSS 13.0 ve doğrulayıcı faktör analizi tekniği için LISREL

8.30 programı kullanılmıştır. Anlamlılık düzeyi .05 olarak alınmıştır. Faktör yapılarını test etmek için açımlayıcı faktör analizi çalışmasıyla belirlenmiş oldan faktör yapıları doğrulayıcı faktör analizine tabi tutulmuştur.

\section{Bulgular ve Tartışma}

Öğretmen Olarak Anne Baba Envanteri (PAAT)'nin Türkçeye uyarlama sürecinde, öncelikle envanter 6 tane İngilizce dil uzmanı tarafından Türkçeye çevrilmiş, daha sonra çeviriler her iki dile hakim olan, iki ayrı kişi tarafindan geri-çevir tekniği ile tekrar İngilizceye çevrilmiştir. Her iki çeviri Türkçe ve İngilizce dillerine hakim olan bir uzman tarafından bire 
bir karşılaştırılarak orijinal envanterdeki özgün ifadelerle anlam karşılığına bakılmış, Türkçe ve İngilizce formlar arasında farklılık olmadığı belirlenmiştir.

Kültürler arası çalışmalarda, ölçülen değişkenler ve kültürlerin kapsadığı bireyler arasındaki farklılıklar hata oluşturabildiğinden ölçme aracı farklı bir kültürde kullanılırken ortak ve güçlü yorumlarla çeviri yapılarak kullanılmalı, farklılıkların en aza indirgenmesi için ölçme aracının maddeleri titizlikle incelenmeli, maddeler dil ve alan uzmanları tarafindan kontrol edilmelidir (Jones, 1987; Öner, 1996; Thornburg vd., 1983).

Ölçek uyarlama sürecinde Türkçeye çevirisi yapılan envanter, uygulama yönergesinin ve değerlendirme ölçütlerinin kapsam geçerliği ve Türk kültürüne uygunluğu için Ankara Üniversitesi ve Çukurova Üniversitesi'nden 13 ayrı öğretim üyesinin görüşlerine başvurulmuştur. Türkçe'ye çevrilmiş olan formlar, uygulama yönergesi, değerlendirme ölçütleri ve envanterin orijinal kopyaları uzmanlara sunulmuş, uzmanlardan envanter yönergelerinin ve değerlendirme ölçütlerinin amaca uygunluk ve anlaşılabilirlik açısından envanterdeki maddeleri anlamsal, deyimsel, deneyimsel ve kavramsal açılardan değerlendirmeleri amacıyla ikili derecelendirme ölçeği üzerinde "Uygun" veya "Uygun değil" şeklinde değerlendirmeleri ve uygun olmadığını düşündükleri envanter maddelerini geliştirmeye yönelik olarak açıklamaları istenmiştir. Uzman görüşleri toplandıktan sonra kapsam geçerliğini test etmek için analizler yapılmıştır. Uzmanlar tarafından verilen puanların aritmetik ortalamasının $\overline{\mathrm{X}} \geq 1,5$ ve $\mathrm{Ss} \leq 1$, uyuşma düzeylerinin $\% 80$ olduğu belirlenmiştir. $\mathrm{Bu}$ durum ölçme aracının, uygulama yönergesinin ve değerlendirme ölçütlerinin orijinal envantere uygun olduğunu göstermiştir.

"Öğretmen Olarak Anne Baba Envanteri" (Parent As A Teacher Inventory-PAAT), geçerlik ve güvenirlik analizleri için uygulamaya hazır hale getirildikten sonra, Adana İl Milli Eğitim Müdürlüğü'nden Adana il merkezindeki resmi ve özel okul öncesi eğitim kurumlarının listesi elde edilerek farklı sosyo-ekonomik düzeyleri temsil eden semtlerdeki resmi ve özel okul öncesi eğitim kurumları tesadüfî örneklem yöntemiyle belirlenmiş ve uygulama için gerekli izinler alınmıştır. Araştırmalar benzer özellik taşıyan bireylerle yürütüldüğünden, uyarlanan ölçme aracının alt, orta ve üst sosyoekonomik düzeylerdeki anne-babalara uygulanabilmesi açısından ölçek uyarlama çalışmasındaki örneklem grubuna her sosyo ekonomik düzeyden anne-babaların seçilmesi için Adana İl Milli Eğitim Müdürlüğüyle görüşmeler yapılmıştır.

Envanterin uygulanacağ 1 okullar belirlendikten sonra yap1-kavram geçerliği için ön uygulama gerçekleştirilmiştir. Adana il merkezi Yüreğir ilçesindeki Milli Eğitim Bakanlı̆̆ı'na bağlı resmi bir ilkokulun anasınıfına devam eden ve normal gelişim gösteren 5-6 yaş çocuklarından 25 çocuk seçilmiştir. Daha sonra bu çocukların anne ve babalarına bireysel olarak, okulda sessiz bir ortamda Öğretmen Olarak Anne Baba Envanteri (PAAT) uygulanmıştır. Uygulama sırasında yeterince anlaşılmayan yönergeler araştırmacı tarafından açıklanmıştır. Ön uygulama sonucunda, yeniden uzman görüşüne başvurulmuş ve görüş ve öneriler doğrultusunda envanterdeki bazı maddelerin daha iyi anlaşılabilmesi için örnek eklemeleri yapılmıştır. Ön uygulama sonucunda güvenirlik katsayısı testin tümü için Alpha $=0.83$ ve madde toplam korelasyonu 0.30 ve üzeri bulunmuştur.

Ön uygulama sonrasında geçerlik ve güvenirlik çalışması için PAAT'ın uygulanacağı okulların yönetici ve öğretmenleriyle görüşülerek çalışmanın amacı ve uygulaması açıklanmıştır. Çalışmaya çocuğu 5-6 yaş grubunda bulunan resmi ve özel sekiz farklı okul öncesi eğitim kurumuna devam eden ve normal gelişim gösteren çocukların anne babaları dahil edilmiştir. Denek sayısı "Basit Tesadüfi Örnekleme" formülü yardımıyla belirlenmiş ve minimum örnek hacmi 267 olarak elde edilmiştir. Ancak cevapsızlık, hatalı cevaplama veya tekrar testlerin dönmemesi vb. nedenlerden dolayı örneklem sayısı artırılmış, bu doğrultuda okullara 5-6 yaşında normal gelişim gösteren çocuğa sahip anne babaların sayısı kadar envanter bırakılmıştır. Öğretmenlerden envanterleri anne babalara dağıtmaları, bireysel olarak cevaplamaları ve aynı çalışmayı 15 gün sonra tekrarlayacaklarını söylemeleri istenmiştir. Dağıtılan 510 envanterden 192'si annelere, 166'sı babalara ait olmak üzere 358 tanesi geri toplanabildiğinden tekrar testler 358 kişiye uygulanmıştır. Tekrar testlerden 7 tanesi geri 
dönmediğinden geçerlik ve güvenirlik çalışması, 191 anne, 160 baba olmak üzere yaklaşı \% 27 civarında örnek hacmi olan toplam 351 kişiyle yapılmıştır. Araştırmaya katılan ebeveynlere ve çocuklarına ilişkin veriler Tablo 1'de sunulmuştur.

Tablo 1. Örneklemde Yer Alan Ebeveynler ve Çocuklarına İlişkin Demografik Veriler

\begin{tabular}{clcc}
\hline \multicolumn{1}{c}{ Özellik } & & Say1 & Yüzde \\
\hline \multirow{3}{*}{ Ebeveyn } & Anne & 191 & 54.42 \\
& Baba & 160 & 45.58 \\
\multirow{3}{*}{ Çocuğun Yaş1 } & Toplam & 351 & 100.00 \\
& 5 yaş & 165 & 47.01 \\
& 6 yaş & 186 & 52.99 \\
Çocuğun Cinsiyeti & Toplam & 351 & 100.00 \\
& Kiz & 167 & 47.58 \\
& Erkek & 184 & 52.42 \\
& Toplam & 351 & 100.00 \\
\hline
\end{tabular}

Araştırmaya katılan 191 anne ve 160 baba katılmıştır. Annelerin 88'i 5 yaş, 103 'ü 6 yaş çocuğuna; babaların ise 77'si 5 yaş, 83'ü 6 yaş çocuğuna sahiptir. 5 yaşındaki 165 çocuğun 85'i kız 80'i erkek; 6 yaşındaki 186 çocuğun 82'si kız, 104'ü ise erkektir.

Envanterin uygulama süreci tamamlandıktan sonra, anne-babalardan elde edilen puanlar SPSS programıyla hesaplanmıştır. Elde edilen verilere ilişkin olarak Öğretmen Olarak Anne Baba Envanteri test, tekrar test puan ortalamaları ve standart sapmaları Tablo 2'de sunulmuştur.

Tablo 2. Öğretmen Olarak Anne Baba Envanteri Test, Tekrar Test Puan Ortalamalarl ve Standart Sapmaları

\begin{tabular}{lcrll}
\hline \multirow{2}{*}{ PAAT } & \multicolumn{2}{c}{ Test } & \multicolumn{2}{c}{ Tekrar Test } \\
& \multicolumn{2}{c}{ n: 351} & $\overline{\mathrm{n}}$ : 351 & \\
\hline Yaratıc1lık & 12.59 & \multicolumn{1}{c}{$\mathbf{S}$} & $\overline{\mathrm{X}}$ & $\mathrm{S}$ \\
Hayal Kırıklığ1 & 22.91 & 2.68 & 12.47 & 1.71 \\
Disiplin & 13.88 & 2.19 & 13.90 & 2.53 \\
Oyun & 31.86 & 3.43 & 31.88 & 2.08 \\
Öğretme/Öğrenme & 19.68 & 2.16 & 19.62 & 2.45 \\
Toplam & 84.30 & 13.23 & 87.90 & 11.11 \\
\hline
\end{tabular}

Tablo 2'de, 351 ebeveynle yapılan testlerde anne-babaların ilk testlerde yaratıcılık alanında puan ortalamalarının 12.59, tekrar test puan ortalamalarının 12.47; hayal kırıklığı alanında ilk testlerden alınan puan ortalamalarının 22.91, tekrar test puan ortalamalarının 22.89; disiplin alanında ilk testlerden alınan puan ortalamalarının 13.88, tekrar test puan ortalamalarının 13.90; oyun alanında ilk testlerden alınan puan ortalamalarının 31.86, tekrar test puan ortalamalarının 31.88; öğretme/öğrenme alanında ilk testlerden alınan puan ortalamalarının 19.68, tekrar test puan ortalamalarının 19.62 olduğu; ilk testlerden alınan toplam puan ortalamasının 84.30 , tekrar test toplam puan ortalamasının ise 87.90 olduğu belirlenmiştir. Elde edilen puanların dağılımı için çarpıklık ve basıklık katsayısına da bakılmıştır. PAAT puan dağılımıyla ilgili olarak çarpıklık katsayısı +2 ile -2 , sivrilik katsayısı ise +5 ile -5 arasında bulunmuştur. Standart normal dağılımda çarpıklık ve basıklık katsayısı sıfirdır (Büyüköztürk, 2010). Kline (1998), normal dağılım özelliğinin sağlanması için, çarpıklık değerlerinin en fazla 3.00, sivrilik değerlerinin de en fazla 10.00 olması gerektiğini belirtmektedir. Buna göre, Tablo 2.6' da çarpıklık ve sivrilik katsayıları incelendiğinde, ölçek puanlarının normal dağılım özelliklerine sahip oldukları söylenebilir. 
Envanterin ölçülmek istenen davranış bağlamında soyut bir kavramı (faktörü) doğru bir şekilde ölçebilme derecesini belirleyebilmek amacıyla yapılan yap1 geçerliğinde faktör analizi tekniğinden yararlanılabildiğinden (Büyüköztürk, 2010) bu envanter uyarlama çalışmasının geçerliği için faktör analizi kullanılmıştır. Yapılan faktör analizinde, önce açımlayıcı faktör analizi (AFA) yapılarak beş faktörlü yapıyı oluşturan faktörlerin her birinin oluşturduğu temel modeller test edilmiş, sonra oluşturulmuş beş faktörlü yapı, madde faktör ilişkileri ve faktörler arası ilişkiyi belirlemek amacıyla doğrulayıcı faktör analizi (DFA) kullanılarak bütünsel olarak test edilmiş ve madde azaltma yoluna gidilmiştir.

Strom (1984) tarafindan geliştirilen orijinal envanterde 1., 6., 11., 16., 21., 26., 31., 36., 41. ve 46. maddeler yarat1c1l1k boyutuyla; 2., 7., 12., 17., 22., 27., 32., 37., 42. ve 47. maddeler hayal kırıklı̆̆ boyutuyla; 3., 8., 13., 18., 23., 28., 33., 38., 43. ve 48. maddeler disiplin boyutuyla; 4., 9., 14., 19., 24., 29., 34., 39., 44. ve 49. maddeler oyun boyutuyla ve 5., 10., 15., 20., 25., 30., 35., 40. ve 45. maddeler öğretme-öğrenme boyutuyla ilgilidir. Yapılan faktör analizi sonucunda yaratıcılık boyutundan 1., 6., 16., 21., 26. ve 36. maddeler, hayal kırıklığı boyutundan 27., 32., 42. maddeler, disiplin boyutunda 3., 8., 23., 28., 43. maddeler ve öğretme-öğrenme boyutundan 15., 20., 30. ve 40. maddeler çıkartılmıştır. Oyun boyutundan hiçbir madde çıkartılmamıştır. Yapılan faktör analizi sonucunda, yaratıcılık boyutunda 11, 31, 41, 46 nolu maddeler; hayal kırıklığ 1 boyutunda 2, 7, 12, 17, 22, 37, 47 nolu maddeler; disiplin boyutunda 13, 18, 33, 38, 48 nolu maddeler; öğretme/öğrenme boyutunda 5, 10, 25, 35,45 ve 50 nolu maddeler bırakılmıştır. Oyun boyutu olduğu gibi bırakılmıştır. Maddelerin çıkartılmasında yük değeri 0.30 'dan büyük olan maddelerin değerlendirilmeye alınması, özdeğer için 1 ya da 1'den büyük olan faktörler üzerinde işlem yapılması ve ortak faktör varyanslarının 0.66'nın üzerinde olması, t değerlerinin 1.96'dan düşük olması etkili olmuştur (Büyüköztürk, 2010). 40 nolu madde çocuğuyla birlikte hiç internet deneyimi olmadığını belirterek boş bırakan 8 kişi olduğu için değerlendirme dışı bırakılmıştır. Yaratıcılık boyutundan 16. (t: -0.42$)$ ve 21 . (t:0.64) maddeler ve disiplin boyutundan 43 (t:1.72) nolu madde, $t$ değerlerinin 1.96'dan düşük olması nedeniyle envanterden çıkartılmıştır. Bunların yanı sira yapılan analizlerde yaratıcılik boyutunda 41 nolu, oyun boyutunda 34 nolu ve öğretme/öğrenme boyutunda 45 nolu madde için orijinal envanterin tersine puanlama yapılması (daima seçeneğine 4 puan) gerektiği saptanmıştır. Yapılan uyarlama çalışması sonucunda, geçerlik güvenirlik sağlaması açısından yaratıcılık boyutu 4 madde, hayal kırıklığı boyutu 7 madde, disiplin boyutu 5 madde, oyun boyutu 10 madde, öğretme/öğrenme boyutu 6 madde olmak üzere envanter toplam 32 maddeye düşmüştür. Madde-toplam korelasyonun pozitif ve yüksek olması, maddelerin benzer davranışları örneklediğini ve envanterin içtutarlığının yüksek olduğunu gösterir. Genel olarak madde-toplam korelasyonu .30 ve daha yüksek olan maddelerin bireyleri iyi derecede ayırt ettiği, .20-.30 arasında kalan maddelerin zorunlu görülmesi durumunda teste alınabileceği veya maddelerin düzeltilmesi gerektiği, .20 'den daha düşük maddelerin ise teste alınmaması gerektiği belirtilmektedir (Büyüköztürk, 2010). Bu doğrultuda envatere madde-toplam korelasyonu .30 ve daha yüksek olan maddeler alınmıştır.

Madde-toplam korelasyonu yapılarak .30 altında kalan maddeler envanterden çıkartılmıştır. azaltma işleminden sonra yaratıcılık boyutu yük değerleri .42-.59; hayal kırıklığ boyutu yük değerleri .31-.66; disiplin boyutu yük değerleri .26-.67; oyun boyutu yük değerleri .35-.62; öğretme/öğrenme boyutu yük değerleri ise .40-.63 arasında değişmiştir. Faktör ortak varyansları ise yaratıcılık boyutunda .18-.27, hayal kırıklığı boyutunda .10-.43, disiplin boyutunda .07-.45, oyun boyutunda .12-.39, öğretme/öğrenme boyutunda ise .16-.40 arasında değişiklik göstermiştir. $\mathrm{T}$ değerleri açısından ise yaratıcılık boyutunda 4.09-5.91, hayal kırıklığ 1 boyutunda 6.02-9.36, disiplin boyutunda 2.76-9.44, oyun boyutunda 5.16-8.69, öğretme/öğrenme boyutunda ise 3.67-9.87 arasında değerler almıştır. Faktör yapısına ilişkin bilgi edinmek için yapılan Path diyagramı sonucunda maddelerin beş faktörde toplandığ analizlerde Ki Kare değerinin 909.05, p değerinin 0.00 ve RMSEA değerinin 0.054 olduğu saptanmıştır. Hesaplanan Ki Kare istatistiğinin anlamlı çıkması, veri matrisinin uygun olduğunun göstergesidir (Büyüköztürk, 2010). 
Verilerin modele uyumunun test edilmesi amaciyla bazı uyum testlerine de bakılmıştır. Bunun için birç̧ok analiz çeşidi bulunmaktadır. Ancak yaygın olarak kullanılan uyum iyiliği indeksleri; X2/sd (Ki kare/Serbestlik derecesi), Karşılaştırmalı Uyum İndeksi (CFI) göstergelerinden olan GFI (uyum iyiliği), AGFI (dengeli uyum iyiliği), RMSEA (yaklaştırmanın ortalama karekök değeri), RMR (ortalama karekök değeri) ve SRMR (yaklaştırmanın standart ortalama karekök değeri) indeksleridir (Gillaspy, 1996). Verilerin uyum iyiliğine ilişkin sonuçlar Tablo 3'de sunulmuştur.

Tablo 3. Elde Edilen Veriler Ile Beş Faktörlü Orijinal Yapı Arasındaki Uyum ve $X^{2}$ Istatistikleri

\begin{tabular}{cccccccccc}
\hline $\mathrm{N}$ & $\mathrm{X}^{2}$ & $\mathrm{Sd}$ & $\mathrm{p}$ & $\mathrm{X}^{2} / \mathrm{sd}$ & GFI & AGFI & SRMR & RMR & 2MSEA \\
\hline 351 & \multirow{2}{*}{909.05} & \multirow{2}{*}{451} & 0.00 & 2.01 & 0.86 & 0.84 & 0.06 & 0.03 & 0.05 \\
\hline
\end{tabular}

Tablo 3'de görüldüğg̈ üzere 351 ebeveyn üzerinden elde edilen veriler sonucunda $\mathrm{X}^{2}$ (Ki Kare) 909.05, Sd (serbestlik derecesi) 451, p değeri 0.00, $\mathrm{X}^{2} / \mathrm{sd}$ oranı ise 2.01 olarak elde edilmiştir. $\mathrm{X}^{2} / \mathrm{sd}$ oranının 5 veya daha az olması model ile verinin uyumunun iyi olduğunu göstermektedir (Gillaspy, 1996). $\chi 2$ 'nin dişında model uyumunu test etmek amaciyla çok sayıda farklı uyum indeksi kullanılmaktadır. Tahmin hatalarının ortalamasının karekökü (Root Mean Square Error of Approximation, RMSEA), iyilik uyum indeksi (Goodness of Fit Index, GFI), düzeltilmiş iyilik uyum indeksi (Adjustment Goodness of Fit Index, AGFI), standartlaştırılmış hata kareleri ortalamasının karekökü (Standardized Root Mean Square Residual, SRMR) karşılaştırmalı uyum indeksi (Comparative Fit Index, CFI), göreli uyum indeksi (Relative Fit Index, RFI), fazlalık uyum indeksi (Incremental Fit Index, IFI), normlaştırılmış uyum indeksi (Normed Fit Index, NFI) araştırmalarda model uyumunu değerlendirmek amacıyla kullanılan uyum indeksleri arasında yer almaktadır (Ilhan ve Çetin, 2014). Yapılan analizlerde GFI indeksi 0.86, AGFI 0.84 olarak elde edilmiştir. GFI'nin 0.85 ve üzerinde olması, model-veri uyumu için yeterli kabul edilmekte (Frias ve Dixon, 2005, Sümer, 2000), AGFI'nin ise 0.80 ve üzerinde olması, kabul edilebilir değer olarak ele alınmaktadır (Jöreskog and Sörbom, 1993). SRMR değeri 0.06, RMR değeri 0.03 ve RMSEA değeri 0.05 olarak elde edilmiştir. RMSEA ve SRMR'nin 0.08 ve daha küçük değerleri, model-veri uyumu için kabul edilebilir değerlerdir (Frias ve Dixon, 2005, Sümer, 2000). Bu göstergelerden anlaşılacağı üzere envanterin verileri orijinal yapısıyla uyumlu bir şekildedir.

Envanterin güvenirliği için madde-toplam puan güvenirliği, Cronbach alfa $(\alpha)$ güvenirliği ve test-tekrar test güvenirliği analizleri yapılmıştır. Yapılan çalışmada test-tekrar test arasındaki zaman aralığı 15 gündür. Öğretmen Olarak Anne Baba Envanteri'nin (Parent As A Teacher Inventory-PAAT) alt boyutlarının ve toplam puan ortalamalarının madde sayısı, Cronbach alfa $(\alpha)$ güvenirlik analizi ve test-tekrar test güvenirliği sonuçları Tablo 4'te sunulmuştur.

Tablo 4. Öğretmen Olarak Anne Baba Envanteri'nin Alt Boyutlarının ve Toplam Puan Ortalamalarının Madde Sayısı, Cronbach Alfa (A) Güvenirlik Analizi ve Test-Tekrar Test Güvenirliği Sonuçları (n:351)

\begin{tabular}{|c|c|c|c|}
\hline Envanter Boyutlar1 & Madde Sayıs1 & $\begin{array}{l}\text { Alfa Katsayıları } \\
(\alpha)\end{array}$ & $\begin{array}{l}\text { Test-Tekrartest } \\
\text { /Kararl1l1k }\end{array}$ \\
\hline F 1 & 4 & 0.31 & 0.81 \\
\hline F 2 & 7 & 0.62 & 0.83 \\
\hline F 3 & 5 & 0.36 & 0.82 \\
\hline F 4 & 10 & 0.59 & 0.84 \\
\hline F 5 & 6 & 0.47 & 0.83 \\
\hline Toplam & 32 & 0.83 & 0.88 \\
\hline
\end{tabular}


Tablo 4’te görüldüğ̈̈ üzere, güvenirlik katsayısı olan Cronbach alfa değerleri $\mathrm{F} 1$ boyutu için 0.31 , F 2 boyutu için 0.62 , F 3 boyutu için 0.36 , F 4 boyutu için 0.59 ve F 5 boyutu için 0.47, Öğretmen Olarak Anne Baba Envanteri (PAAT) toplam puan ortalaması açısından ise Cronbach alfa değeri 0.83 olarak bulunmuştur.

Cronbach alfa $(\alpha)$ güvenirliği, test maddelerine verilecek olan cevabın üç veya daha fazla olması durumunda kullanılmaktadır. Güvenirlik katsayısının .70 ve daha yüksek olması, test puanlarının güvenirliği için genel olarak yeterli görülmektedir (Büyüköztürk, 2010). Elde edilen sonuçlarda alt boyutlara ilişkin Cronbach alfa değerinin düşük olduğu, ancak toplam puan açısından istenilen bir değer olduğu görülmektedir. Envanterin iç tutarlılığındaki bu durum, ölçülen özelliğin ve faktörlerde yer alan madde azlığından kaynaklanmış olabilir.

İç tutarlığın düşük olması nedeniyle test-tekrar test güvenirliği sonuçlarına da bakılmıştır. Test-tekrar test güvenirliği ölçme araçlarının güvenirliğini değerlendirmede kullanılmaktadır (Büyüköztürk, 2010). Test-tekrar test korelasyon katsayılarına bakıldığında, F 1 boyutu için 0.81 , F 2 , ve F 5 boyutları için 0.83 , F 3 boyutu için 0.82 , F 4 boyutu için 0.84 olduğu toplam değerinin ise 0.88 olduğu görülmektedir. Bu değerler ölçeğin güvenilir olduğunun bir göstergesidir.

Young Hee, Kae Sook ve Shin-Jeong (2009) tarafından Öğretmen Olarak Koreli Ebeveynler Envanteri'nin (KPAAT) geçerlik güvenirliğini belirlemek amaciyla çocuğu anaokuluna giden 187 ebeveyn ile yapılan çalışmada, ebeveynlerin çocuk yetiştirme tutumları ebeveynlerin envantere verdikleri cevaplarla değerlendirilmiştir. Güvenirlik için iç tutarlılık, Cronbach's Alpha Katsayısı ile değerlendirilmiş, yapı geçerliği ise faktör analizi ve madde analizi kullanılarak analiz edilmiştir. Sonuçta, envanter toplamı için alfa katsayısı 0.88 bulunmuştur. Madde analizinde, madde içi korelasyon katsayısı -0.029-0.781, düzeltilmiş madde toplam korelasyon katsayıs1 0.012-0.737, madde-alt alan korelasyon katsayısının 0.509-0.817 arasında değiştiği bulunmuştur. Alt alan-toplam korelasyon katsayısı ise 0.965 , 0.711 olarak bulunmuştur. KPAAT'ın iç yapı güvenirliği kabul edilebilir oranlarda olmasına karşın KPAAT envanterinin geçerliğinin geliştirilme çalışmalarına ihtiyaç duyduğu belirtilmiştir.

\section{Sonuç ve Öneriler}

5-6 yaş grubunda normal çocuğa sahip anne-babalarla yapılan PAAT geçerlik güvenirlik çalışması sonucunda, 32 maddeye indirgenmiş olan envanter yeniden düzenlenmiştir. Sonuçta 7, 18, 25, 28 nolu maddeler yaratıc1lı boyutuyla; 1, 4, 8, 11, 14, 22, 29 nolu maddeler hayal kırıklığ boyutuyla; 9, 12, 19, 23, 30 nolu maddeler disiplin boyutuyla; 2, 5, 10, 13, 15, 17, 20 , 24, 26, 31 nolu maddeler oyun boyutuyla; $3,6,16,21,27,32$ nolu maddeler öğretme/öğrenme boyutuyla ilgili olup 1, 2, 3, 7, 8, 10, 11, 12, 15, 17, 18, 20, 21, 23, 25, 26, 27, 28, 29, 31, 32 nolu maddelerde daima 4 , s1klıkla 3 , nadiren 2 , asla 1 puan; $4,5,6,9,13,14,16,19,22,24$, 30 nolu maddelerde daima 1, sıklıkla 2, nadiren 3, asla 4 puan almaktadır. Yapılan uyarlama çalışması sonucunda Öğretmen Olarak Anne Baba Envanteri (PAAT), geçerli ve güvenilir bulunmuştur.

Uyarlama çalışması yapılan orijinal envanter 3-9 yaş arası çocuğa sahip annebabaların çocuk yetiştirme tutumlarını değerlendirmektedir. Bu çalışmada ise uyarlama ve geçerlik-güvenirlik çalışması, 5-6 yaş çocuğa sahip anne babalarla yapılmıştır. Aynı uyarlama çalışması farklı yaş grubu çocuğa sahip anne-babalar ile de yürütülebilir. Anne babaların çocuk yetiştirme tutumlarını ortaya koymaya ilişkin yeni ölçme araçları geliştirilebilir ve Öğretmen Olarak Anne Baba Envanteri (PAAT) ileride daha farklı heterojen gruplarda ele alınarak gözden geçirilebilir ve çeşitli bölgelerde geçerlik güvenirliği tekrarlanarak maddeler yeniden değerlendirilebilir.

\section{Kaynaklar}

Beckert, T.E., Strom, P.S, Strom, R.D., Yang, C., Huang, N., \& Lin, Y. (2004). Parent expectations of young children in Taiwan. Early Childhood Research \& Practice 6(2), $1-11$. 
Büyüköztürk, Ş. (2010). Sosyal bilimler için veri analizi el kitabı. (3. Baskı), Ankara: PegemA.

Büyüköztürk, Ş., Çakmak, E. K., Akgün, Ö. A., Karadeniz, Ş. ve Demirel, F. (2008). Bilimsel araştırma yöntemleri, (1. Basım), Ankara: Pegem Akademi.

Demirkaynak, Ö., Aktaş, N. ve Hasipek, S. (2006). 3-6 yaş grubunda çocuğu olan annelerin beslenme bilgi düzeyleri ve beslenme alışkanlıkları. Avrupa Birliği Sürecinde Okul Öncesi Eğitimin Geleceği Sempozyumu, 112-123, İstanbul: Ya-pa,

Elibol, F. (2007). 12-36 aylar arasında çocukları olan annelere verilen grup eğitiminin annelerin anne-babalık görevlerinde öz yeterliliklerine yönelik katkısinın incelenmesi. Yayınlanmamış doktora tezi, Hacettepe Üniversitesi, Sağlık Bilimleri Enstitüsü, Çocuk Gelişimi ve Eğitimi Programı, Ankara.

Frias, C.M., \& Dixon, R.A (2005). Confirmatory factor structure and measurement invariance of the memory compensation questionare. Psychol Assess, 17(2), 168-178.

Gillaspy J.A. Jr (1996). A primer on confirmatory factor analysis. Güneybatı Eğitim Araştırmaları Birliğinin Yıllık Toplantısı, Austin, Texas. New Orleans.

Grotevant, H.D., \& Carlson, C.I. (1989). Family assessment. (1. Bask1), 456-459, Newyork: The Guilfod Pres.

Hellen, K.A. (1999). Maternal attitudes and their influence on the creativity level of preschool children. master of science in family and consumer sciences (unpublished), West Virginia University, College of Agriculture and Forestry, 1-80 p., Morgantown, West Virginia.

Hull, C.H., \& Nie, N.H. (1979). SPSS update. McGraw-Hill, Incorparated, Newyork.

İlhan, M. ve Çetin, B. (2014). LISREL ve AMOS Programları Kullanılarak Gerçekleştirilen Yapısal Eşitlik Modeli (YEM) Analizlerine İlişkin Sonuçların Karşılaştırılması. Ĕgitimde ve Psikolojide Ölçme ve Değerlendirme Dergisi, 5(2), 26-42.

Jones, E. (1987). Translation of quantitative measures for use in cross-culturel research. Nursing Research, 36(5), 324.

Kaya, Ö.M. (2002). Okul öncesi eğitim kurumlarında uygulanan programlara ailelerin ilgi ve katılımları ile okul öncesi eğitim kurumlarının aile eğitimine katkısı konusunda annebaba görüşleri. Yayınlanmamış yüksek lisans tezi, Anadolu Üniversitesi, Eğitim Bilimleri Enstitüsü, Okul Öncesi Öğretmenliği, Eskişehir.

Kline, R.B. (1998) Principles and Practice of Structural Equation Modeling, The Guilford Press: New York.

Öner, N. (1996). Türkiye'de kullanılan psikolojik testler. (2. Bask1), 628, İstanbul: Boğaziçi Üniversitesi.

Özbey, S. (2010). Okul öncesi çocuklarda uyum ve davranış problemleriyle başa çıkmada ailenin rolü. Aile ve Toplum Dergisi, 6(21), 9-16.

Percira, F.I.A., Canavarro, C., Cardese, M.F., \& Mendonça, D. (2008). Parents of parental rearing styles and child behaviour problems among Portuguese school-aged children. Journal of Child and Family Studies, 15(5), 735-751.

Strom, R.D., \& Hill, J. (1979). Determining a parent curriculum. Journal of American Indian Education, 19(1), 23-29.

Strom, R.D. (1982). The parent as a teacher inventory and manual. Scholastic Testing Service, Chicago.

Strom, R.D. (1984a). Parent as a teacher inventory manual. Scholastic Testing Service, Bensenville, IL.

Strom, R.D. (1984). The home-school partnership: learning to share accountability. The Clearing House, 57(7), 315-317.

Strom, R., Wurster, S., Betz, M.A., Daniels, S., Graf, P., \& Jansen, L. (1984). A comparasion of West German and guestworker parent's childrearing attitudes and expectations. Journal of Comparative Family Studies, 15(3), 427-440.

Strom, R. (1995). Parent as a teacher inventory (Paat). Scholastic Testing Service, Bensenville, IL. 
Sümer, N. (2000). Yapısal eşitlik modelleri: temel kavramlar ve örnek uygulamalar. Türk Psikoloji Yazılart, 3(6), 74-79.

Tezel-Şahin, F. ve Özyürek, A. (2010). Anne baba eğitimi ve okul öncesinde aile katılımı, 2330, İstanbul: Morpa.

Thornburg, K.R., Ispa, J., Gray, M. M., \& Ponder, H. (1983). Parent as a teacher inventory: a statistical factor analysis. Journal of Experimental Education, 51(4), 200-202.

Warner, L., \& Sower, J. (2005). Educating young children. 397-398, Newyork: Pearson education.

Young Hee, K., Kae Sook, K., \& Shin-Jeong, K. (2009). Test of the Korean parent as a teacher (KPAAT) Inventory-Focusing on the Parents of Preschoolers. J Korean Acad Child Health Nurs, 15(3), 314-324.

\section{Extended Abstract}

\section{Introduction}

The family seems to be the most effective and economical system for fostering and sustaining the child's development. When families are involved in their children's education in positive ways, children can achieve higher grades and test scores, have better attendance at school, demonstrate more positive attitudes and behaviour. When parents are involved in their children's education, both children and parents are likely to benefit. Most parents want feedback about their level of competence about child development.Practitioners and researches in child and family development are often in need of an efficient method for measuring parenting attitudes. More recent research has examined the effect of a variety of parental practices on the educational outcomes of children ranging in age from preschool to high school and children growing up in different social groups. The aim of this research is to adapt the Parent as a Teacher Inventory (PAAT) to Turkish. This instrument is used to measure attitudes of parents who have 3- to 9 year-old children. PAAT instructions inform respondents that they read statements on feelings about their child. For each statement, they are to circle only one answer. PAAT is designed to examine five aspects (creativity, control, play, frustration, and teaching-learning) of interaction between parent and child.

\section{Method}

In this study, PAAT was administered to 351 parents (191 mothers and 160 fathers) living in Adana, Turkey. All subjects were volunteer parents and had children between five and six years of age. The Turkish parents were selected from eight kindergartens affiliated to the Ministry of National Education in Adana. All of the people were volunteer about joining research. Firstly, It gave knowledges about the inventory and aim of the research. It was interviewed with them and It wanted for selecting their ansvers. Factorial structure, criterionrelated validity, test retest reliability and cronbach alpha internal consistency of the Turkish version of the inventory were assessed by various statistical analyses.

\section{Result and Discussion}

The results of the factor analysis of the scale which was held to reveal the factor structure of the scale seem similar to the original scale. Cronbach alpha correlation coefficient of the scale was found as $\alpha=0,83$. Test-retest reliability coefficient was found as 0,88 . Fit index values of the model were (RMSEA =.05, RMR=.03, SRMRI=.06, GFI=.86, $A G F I=.84, \mathrm{X}^{2} / \mathrm{sd}$ 